\title{
Whistleblowers in peril
}

The US Congress should reverse a pernicious removal of protection of federal employees.

$\mathrm{n}$ another worrying instance of its tendency to quietly arrogate new powers to itself, the Bush administration has reversed two decades of precedent and declared that important whistleblower protections in the Clean Water Act do not apply to federal workers.

This binding change in the interpretation of the law was instigated by a top Department of Justice lawyer a year ago. Steven Bradbury, acting assistant attorney-general in the department's Office of Legal Counsel, gave a straightforward reason for his decision: the Clean Water Act does not list the US government as a 'person' in its definition of employers from whom whistleblowers may seek redress in the event of retaliation by their bosses. He concluded that the ancient legal doctrine of sovereign immunity — which says the government must explicitly consent to be sued - makes the federal government immune from the whistleblower provisions in the law.

The water law was written to protect workers in the private and public sectors who report breakdowns in its enforcement, manipulations of science, or clean-up failures. Its whistleblower provisions essentially apply to any action a worker might take in a sincere effort to do a good job - and hence go further than a different, government-wide whistleblower law that is still in place but that protects only the reporting of gross mismanagement or violations of law.

The water law's provisions have real teeth: whistleblowers who are found to have legitimate complaints are eligible for reinstatement to lost jobs, back pay, and compensatory damages for loss of reputation and emotional distress - damages that in the past have ranged in the tens of thousands of dollars.

Exempting federal employees would expose to retaliation some 170,000 members of the federal workforce in a dozen different agencies, from the Forest Service to the US Geological Survey, who might make efforts in good faith to see that the law is properly enforced. Scientists could feel this particularly strongly, as the problems they encounter - such as the skewing of a methodology or the removal of a conclusion from a report - don't typically violate a law. This change is bound to suppress their willingness to report such events. Superficially, the justice department has made a defensible case. But it goes against two decades of precedent during which the Department of Labor adjudicators charged with administering whistleblower law repeatedly rejected arguments for the government's sovereign immunity under the water law. Legal doctrine holds that, when an agency such as the labour department has a long-standing interpretation of a law, as in this instance, and Congress does nothing to change it, it can be assumed that Congress accepts that interpretation.

But what is particularly disturbing about this change is the way it was brought in under the radar, remaining unpublished for 12 months and unknown to the federal workers potentially affected by it. It only became public last week, when the advocacy group Public Employees for Environmental Responsibility released a letter from Bradbury, which it obtained under the Freedom of Information Act after stumbling upon a reference to it in a whistleblower complaint. This is hardly a fitting approach to jurisprudence in a purportedly open and democratic society.

It is common knowledge that the Bush administration has fought against implementing more stringently protective environmental laws, and its "What is particularly disturbing about this change is the way it was brought in under the radar." enforcement of existing laws has been weak to a fault; according to the justice department's figures, government requests for criminal prosecutions of environmental lawbreakers fell by half in the five years to 2005. In such an atmosphere, whistleblowers within the government become a key defence against further erosion of environmental standards. Removing their protections seems all but certain to hasten this erosion.

There is a possible remedy, however: Congress should amend the Clean Water Act to define the US government as an employer against whom whistleblower complaints can be brought.

\section{Flickers of consciousness}

\section{Brain scans are forcing researchers to reconsider the state of outwardly unresponsive patients.}

\rceil he news that a patient in a vegetative state has shown signs of awareness of the outside world, and an ability to perform mental tasks on request (see page 132), marks a turning point in the investigation of these enigmatic medical conditions. It also means that neuroscientists have some serious thinking to do.

The evaluation of vegetative states, in which patients are often 'awake' but show no outward sign that they are aware of themselves or their environment, has always been difficult, simply because of the huge variability in the nature and severity of the brain injuries that underpin them. What is often so heartbreaking for friends and relatives is that the patient's mental quality of life is unknowable.

In the wake of the latest research (A. M. Owens et al. Science 313, $1402 ; 2006)$, the inevitable calls for all 'vegetative' patients to be considered internally conscious should not be heeded. This case has little bearing on ethical questions over whether or not the most severe cases should be denied treatment and allowed to die. Clearly, for those with the bleakest prognosis - those who have shown no improvement over a period of at least 12 months and are categorized as being in a 'permanent vegetative state' - the chances of finding any sign of awareness are negligible.

But when considering those at the less severe end of the spectrum, such as the British patient at the heart of the latest research, the new 